for profit were held in contempt which produced the disregard and final destruction of liberty which. we now witness.

I shall conclude with an illustration of what I have said about the role of some of the great men of science of Imperial Germany. The famous physiologist Emil du Bois-Reymond was one of the leaders of the movement anxious to extend the methods of natural sciences to social phenomena and one of the first and most effective advocates of the now so fashionable view that "the history of natural science is the real history of mankind"13. It was also he who uttered what is perhaps the most shameful statement ever made by a man of science on behalf of his fellows. "We, the University of Berlin," he proclaimed in 1870 in a public oration as rector of the University, "quartered opposite the King's palace, are, by the deed of our foundation, the intellectual bodyguard of the house of Hohenzollern"14. The allegiance of the German scientist-politicians has since changed, but their respect for freedom has not increased. And the phenomenon is not confined to Germany. Has not Mr. J. G. Crowther recently, in a book which develops views so similar to du BoisReymond's, undertaken to defend even inquisition because, in his view, it "is beneficial to science when it protects a rising class"15 ? On this view clearly all the persecutions of men of science by the Nazis after they came to power could be justified-for were not the latter then a "rising class"?

\footnotetext{
${ }^{1}$ P. M. S. Blackett and others, "The Frustration of Science", Allen and Unwin (1935), p. 142.

"H. D. Dickinson, "Economies of Socialism", Oxford University Press (1939); ' O. Lange and F. M. Taylor, "On the Economic Theory of Socialism", University of Minnesota Press (1938) F. A. Hayek, Economica, N.S., 7 (1940).

s Final Report of the Temporary National Economic Committee ("T.N.E.C."), U.S.A., 77th Congress, 1st Session, Senate Document No. 35,89 .

4 L. Hogben, "Education for an Age of Plenty", British Institute of Adult Education (1937), p. 10.

${ }^{5}$ R. Bain, Social Philosophy, 230 (April, 1939).

${ }^{6}$ F. B. Jewett and W. R. King, NATORE, 146, 826 (1940).

?W. Lippmann, "The Good Society", Little, Brown and Co. (1937); M. Polanyi, "The Contempt of Freedom", Watts and Co. (1940) W. Sulzbach, Ethics, 50 (April, 1940); F. A. Hayek, "Freedom and the Economic System", University of Chicago Press (1939).

${ }^{8}$ I. Robbins, "Economic Planning and International Order", Macmillan (1937)

'F. Mackenzie (ed.), "Planned Society", Prentice Hall (1937), p. xx

${ }^{10}$ Final Report of the T.N.E.C., p. 20.

${ }^{11}$ Spectator, 337.(March 3, 1939).

12 Final Report of the T.N.E.C., p. 5.

${ }^{13}$ Emil du Bois-Reymond, "Kulturwissenschaft und Naturwissenschaft"' (1879).

14."A Speech on the German War", Delivered on August 3, 1870, before the University of Berlin', by Emil du Bois-Reymond, at that time Rector. London, Rd. Bentley (1870), p. 31 .

is J. G. Crowther, "The Social Relations of Science", Macmillan $(1940)$, p. 333
}

\title{
THE SCIENTIFIC APPROACH TO COLONIAL DEVELOPMENT*
}

\section{By The Right Hon. LoRd Hailey, G.C.S.I., G.C.M.G., G.C.I.E.}

$\mathbf{I}^{\mathrm{N}}$ $N$ discussing colonial conditions, I shall in the main limit myself to those prevailing in the British Colonies. The character of the British colonial empire was modified as a result of the expansionist policy of the latter part of the last century. The Indian Empire and Burma have, of course, never been ranked as colonies. Up to about the eighties of last century, therefore, the Colonies comprised mainly Ceylon and a small part of Malaya in the eastern hemisphere, a number of trading settlements on the coasts of Africa, and in the western hemisphere, the old British possessions in the West Indies. The period of expansion added in Africa alone an area roughly equal to that of British India, together with parts of Borneo, an extended area in Malaya, and some of the Southern Pacific islands. The new territories were largely tropical in character; but, what is more important, the majority of their popúlations were at a stage at which they had needs, both material and social, far greater than those of some of the older dependencies. Judged

* Substance of a paper read at the Conference on Science land World Order on September 27. in terms of approach to our own type of civilization, they were far more backward. On the other hand, we had then available to us the result of much previous experience of colonial development; above all, we had by this time at our service an amount of knowledge regarding the employment of the applied sciences in social development which was far in advance of that possessed by our predecessors. We had another advantage. Earlier in the last century, tropical products (excluding, of course, certain of the minerals, and the precious metals) were in demand only in the luxury market of the more highly developed countries. But the rapid growth of standards of living in those countries has made the luxuries of our grandfathers the necessities of whole populations to-day. Such things as cocoa, the great range of vegetable oils, coffee or bananas are typical of the tropical products which have become essential to the general population of Europe and America, and thus can assist the tropical peoples in financing the social services needed to improve their standards of life.

We had also at our service a growing store of 
knowledge about the social customs of primitive peoples. It may be that the existing customs of these people in such matters as the holding of property, the regulation of conduct by tribal or community ties, and the like, has had its analogy in the past history of our own and other highly organized peoples. But we are now divided from the primitive peoples by a gulf which makes the process of their adjustment to modern civilization far more difficult than that of many of the Eastern peoples. Our anthropological study may, at the period of which I am speaking, have been interested in the form rather than in the function of custom. But we had the means of appreciating the fact that the gulf could not be suddenly closed by a hasty substitution of our own social conceptions and practices; but must be bridged by a studied adaptation of existing custom to modern uses.

I can best illustrate the character of the problem with which $I$ have set out to deal, if I ask how far we have actually availed ourselves of these opportunities in planning the development of the new areas which the events of the latter half of the last century brought into our possession. We need not concern ourselves here with the preliminary stage through which all colonial development must pass, I mean the introduction of law and order, and the provision of those more elementary requirements, in the form of communications and the like, which will enable the population to begin building up its material existence. We are concerned here with the secondary stage, of which the chief feature is, or should be, the conscious planning of the improvement of its standards of life.

We can afford to avoid at this point any discussion as to the nature of the ultimate objective of this development-whether, for example, we desire to Europeanize the dependent peoples, or what is the nature of the synthesis between the indigenous culture and our own culture which we seek to attain. These are no doubt questions which must have their answer at some stage, but the answer is one which is in the end more likely to be provided by the dependent peoples themselves than by us. I confine myself here to matters which we cannot doubt to be within our grasp, given a due attention to careful planning and systematic execution.

We must see that the colonial peoples have that type of nutrition which will establish the necessary measure of resistance to disease. We must secure for them a subsistence adequate to provide the strength necessary for sustained effort in cultivation or industry. They must have access to medical facilities for dealing with physical disorders, epidemic or otherwise; and access to such measure of popular instruction as will enable the mass of people to adjust themselves to the needs of new economic and cultural conditions. These are fundamentals, and precondition all further social progress.

But planning, even at this early stage, cannot halt there. We interpret economics to-day in terms of welfare, not of wealth ; but it is 2 condition of welfare that the Government should itself have the means of raising finance for capital works or for the provision of social services, and that the population should be furnished with the means of acquiring articles which a non-industrialized country must necessarily import. All the exportable assets of the territory, whether in the form of metals or of exportable crops, must therefore be turned to the best account. But this must at the same time be effected on terms which will avoid prejudice to the primary claims of subsistence production or undue disturbance to a social economy not yet adjusted to the needs of industrial life.

How far have we planned scientifically for development on the lines which I have just described? For I take it that the use of science in colonial development means just this, that we start by surveying the whole field in order to get the problems which it presents into proper alignment, and afterwards proceed systematically to their solution, using the most expert agencies available for advice as to the methods to be employed, and expending the resources at our com. mand in the order which the relative importance of our problems indicates.

It is doubtless unduly idealistic to suggest that we could ever have proceeded on lines involving so much prevision and systematic procedure as this involves. It is at all events clear that we did not do so. We have, for example, in many instances allowed concentration on the cultivation of export crops to outweigh the needs of subsistence production, with results no doubt less disastrous than those which at one time attended the use of the culture system in the Netherlands East Indies, but sufficiently grave to require legislation compelling a minimum subsistence cultivation, in order to prevent famine. It is only in the last few years that we have inaugurated a general survey of nutritional conditions in the Colonies. It required the revelations regarding the ravages of sleeping sickness in the neighbourhood of Lake Victoria during the years 1901-1905, where we owed much to inquiries initiated by the Royal Society, to bring home to our administrations the deplorable health conditions prevailing in many parts of Africa, and there are still many areas in which no general survey of these conditions has yet been made. The extent of popular education was for long dependent on missionary initiative, and the State did not control 
the curriculum. It is only of very recent years that we have realized the widespread menace of soil erosion and the need for special measures for conserving soil fertility.

Passing to another field, there are many territories where geological survey has been very superficial, and the discovery of mineral deposits has been left to the initiative of individual prospectors, who have been primarily interested only in the precious metals. Land survey has in some cases been so exiguous that railways have had to be realigned at great cost owing to the lack of accurate maps. Or take yet another field. Native land tenure systems have in Africa still to come under comprehensive survey, though agricultural progress must largely depend on the evolution of a definite and easily recognizable system of land rights. Recruitment of labour for industrial enterprises has not until lately been regulated by any programme based on the capacity of different areas to provide man-power without undue social disturbance or interference with subsistence cultivation. It has been left to the management of these enterprises to investigate the most suitable dietary for labour and to apply it at their own discretion.

We must readily admit the obstacles which have stood in the way of a systematic planning of development. No one can justly overlook these, just as no one should underestimate the vast improvement which we have actually made in the life of the dependent peoples, or the services which the high sense of duty of the administrative staff has rendered to them. Nor must one overlook the many contributions which have been made, especially of late years, by our scientific bodies and the labours of individual men of science. It is sometimes said, that if we have failed ta be more systematic in our policy of development, it is because we are not ourselves either a very logical or a scientifically minded people. In our own national life we prefer to act on a sense of expedience rather than on principle; we trust to improvisation rather than to logical scheming, holding that this is more flexible and more readily adjustable to the complexities of actual situations than are the results of more abstract thinking.

Our colonial policy has in the past been dominated by certain traditions derived from our own political instincts, and by the conditions in which we originally acquired jurisdiction over our dependent peoples. We saw our first duty in protecting them from exploitation and misrule and in fitting them to maintain, in a political sense, their own position in the world. That tradition was far from unworthy, but it may be that it unduly diverted our attention from the need of pursuing a constructive policy of improvement in the physical conditions and the standards of life of these people. In the second place, we have in the past tended in our own domestic life to look on the State chiefly as a political organization, and not as one of which the primary function is the promotion of the social welfare, the health and the standards of life of its citizens. This generation has seen a radical change in our conception of the functions of the State, and with it has come a new and more constructive outlook on the activities which should engage the attention of a colonial administration.

This changed conception of the functions of the State has had a marked influence on the attitude of the British public itself towards its colonial obligations. It was in the past usual to make an appeal to a sense of trusteeship, a trusteeship which, in a well-known phrase, ought to be exercised alike in the interests of dependent peoples and those of civilization. But that form of appeal had its limitations. It was capable of a great variety of interpretations, and it supplied no standard for action. It left it open to the public to feel that it could satisfy its sense of obligation by the maintenance of a humane system of administration and by taking a liberal view of the political future of its dependants. But the new conception of the functions of the State puts our colonial obligations on a concrete plane, and one with which the public is not unfamiliar.

It is the general acceptance of this new conception of the State in relation to the provision of social services which rendered it relatively easy to secure the liberal provision of funds guaranteed by the Colonial Welfare Act passed in 1940. We started at the outset with the feeling that a Colony should be self-supporting. We advanced a further stage when the Colonial Development Fund Act of 1929 made it possible to spend up to a million pounds a year on assistance to certain of the social services, or on types of inquiry which the Colonies were not able to finance. The Act of 1940 , however, is a final recognition that further development cannot be achieved without more far-reaching and more consistent assistance.

It is now the task of the administrator to make a full use, and at the same time a more scientific use, of this position. Let me indicate some of the directions which the more scientific use of the opportunities now presented might profitably take. I will begin with some of our more fundamental needs. In the first place, we need to place our demographic information on a more satisfactory basis. Even the total population of some of our territories is a matter of assumption and dependable vital statistics are generally unobtainable. The extension of land survey is essential, at all events so far as regards geodetic triangulation, in order to 
provide the network within which cadastral survey can be conducted as it becomes necessary. We must not repeat the experience of South Africa, which paid heavily for its delay in carrying out the scheme of triangulation put forward by Sir David Gill in the seventies of last century. Again, the fuller knowledge of our colonial assets demands an expanded service of geological survey; the discoveries made by the Government geological staff in the Gold Coast and Sierra Leone, show how ample a return the Government revenues can secure for the small outlay involved. To-day much of the energy of our small geological staff is diverted in some areas to the provision of water supplies or the regulation of mining licences. I have referred to the inauguration of a nutrition survey, a movement largely stimulated by the work of Sir John Orr and his colleagues in Kenya, but the specialist staff engaged is relatively small, and in only one or two cases has the survey been associated with the sociological survey which must be an essential part of a study of this nature. It is not enough to know if a dietary is inadequate or ill-balanced; we must know also the social habit which determines its selection or hinders the use of available substitutes.

As regards health work I have already pointed out the absence in many territories of a complete survey of health conditions. There have been studies carried out of particular localities which have proved of the highest value, but much has still to be done in this direction. Thus, to take an example from Africa, we know as yet very little about the exact range of the 'dormant' or 'silent' stage of yellow fever, and we should indeed know less but for the aid given by the Rockefeller Foundation. The incidence of tuberculosis is still unexplored, and there is reason for believing that previous assumptions on the incidence of leprosy are largely incorrect. It is essential again that we should have a more precise knowledge of the effects of tropical and particularly equatorial climates on the physical condition of Europeans. It is equally necessary that we should know whether there are any such fundamental differences in the physical constitution of tropical peoples as will effect the application to them of the European system of curative medicine.

Our work of survey must necessarily include also studies on the social side. One such is that into land tenures, to which $\mathrm{I}$ have already referred. Another is the study of the procedure of native marketing, on the improvement of which depends the expansion of the internal economy of the Colonies. A third is the investigation of the extent to which indigenous customary law affords a basis for the formulation of a uniform legal system which will adjust the procedure of European law to the requirements of the more primitive populations.
It is to be hoped that much of this work will become practicable when the special fund for research provided by the Act of 1940 becomes available after the War. The provision which Parliament has thus made for colonial research is in itself significant of the new order of ideas, and I know of no parallel to such a measure in other countries. But survey, though essential to system. atic planning, is only part of a scientific approach to colonial development. There still remains the need for research into the wide range of specific problems arising in the field both of the applied and social sciences, which require local investigation either because they are peculiar to colonial conditions or because, though more general in character, they present features which can only be studied within the Colonies themselves.

Here I suggest that there are certain guiding considerations. It is advisable that the facilities afforded by our great imperial institutions of research should be utilized to the fullest extent and that the energies of colonial research workers should be strictly limited to problems requiring local inquiry. One is struck by the limitations imposed on the research worker by isolation alike from the assistance and the criticism of professional colleagues. The well-known study into the alleged mental deficiency of Africans made a few years ago at Nairobi would have taken a very different form if it had been made in the more critical atmosphere of a European intellectual centre. Secondly, we should seek to group colonial research workers into suitable centres and to bring their work under some form of professional direction. At present the staff engaged in research is liable to have its energies diverted to routine work, and when it undertakes longer range inquiries the subject is often dictated by its own choice or pressed on it by the local interests which are in a position to influence its services.

There arises a further problem for which I have some difficulty in suggesting a solution. It is possible to envisage group centres for agricultural, medical or similar research, each under its own professional direction. But how are the efforts of these different departments of inquiry to be co-ordinated? Few of the major problems of the Colonies can be solved by specialists in one branch of inquiry alone. What agency is there which can exercise joint direction over these different interests in research, or at all events decide the relative importance of their application in practice? That is a question to which the lay administrator would certainly welcome an answer.

Let me add one final consideration. I have purposely refrained from instituting comparisons which might suggest that other colonial powers have given either greater or less attention to 
scientific planning than we have ourselves. I have therefore made no reference to the extensive study of the economics of production made by the Dutch in their East Indies, or the use made in the French Colonies of their metropolitan research institutions, such as the Pasteur Institute, of the scientific approach made by the Belgians to certain aspects of medical work and to the problems of labour supply, or the unusually extensive programme of scientific inquiries with which Italy inaugurated its regime in Ethiopia. But if any lesson would seem likely to emerge from such a comparison it is this. Admitting a certain difference in policy and ideals, there is a very striking resemblance in our concrete problems. That we should seek for every means of co-operation in solving them is so obvious as to be commonplace. But how far does this co-operation extend at present? In one sense, of course, all scientific inquiry is co-operative in so far as its published results are the common possession of all men of science. We have again had instances, though not as many as might be expected, of international conferences on scientific subjects which have a bearing on colonial development. But there are not many instances of combined planning for dealing with specific problems in the field of the applied or social sciences. An outstanding instance to the contrary is that of antilocust research, which has become largely international in character. There are perhaps other instances, but they must be few. Their restricted scope justifies, at all events, the suggestion that a modern world which can combine to control the production of tea or rubber, or tin, or copper, in the interests of an investing public, might well find the means of exhibiting a greater solidarity in dealing with issues vital to the welfare of the colonial peoples.

\section{OB ITUARIES}

Prof. N. K. Koltzov

$\mathrm{O}^{\mathrm{N}}$ Decermber 2, 1940, science suffered a severe loss in the death of Nicolai K. Koltzov, the great Russian biologist. Born in Moscow in 1872 and educated at the University of Moscow, Koltzov began research as a comparative anatomist and his first paper was on the development of the amphibian pelvis. Other early work of his was in the direction of the development of the head, especially in cyclostomes.

When Koltzov turned his attention, however, to the structure of spermatozoa, beginning with those of the decapod Crustacea, which are extremely elaborate, he found himself entering a line of work which was to continue throughout his life. From 1905 onwards he was more and more fascinated by the structures in cells which seem to maintain their morphological shape. While others arrived at the conception of fibre-molecules, anisometric polymerized particles, etc., from the study of mammalian muscle fibres, Koltzov approached it from the study of cells such as crustacean spermatozoa and contractile fibres such as the stalks of Vorticella. Already in 1912, long before any X-ray analysis had been applied to fibres of biological origin, Koltzov proposed in Priroda that much of the morphology of cells is due to the actual shape of the molecules within them. Even in 1928, when he elaborated these views in a classical paper in the Biologisches Centralblatt, he had little more to go upon than the polypeptide chain conceptions of Emil Fischer. The establishment of the anisometric character of myosin particles by optical and viscosimetric methods did not come to confirm him until after 1930. In Russia the view that the shape of cells is determined largely by "solid" protoplasmic "skeletal" elements immersed in more liquid or semi-liquid protoplasm, is known as "Koltzov's Principle", and as time goes on this term may come to be more widely used. In 1928, too, Koltzov suggested that the chromosome might perhaps be regarded as a protein giant-molecule, of which genes might be side-chains; a conception which has since been found stimulating and fruitful.

Koltzov's papers, not very numerous, but all on fundamental problems, were collected into a book "Organisatsia Kletke" ("The Organization of the Cell"; Moscow, 1936) but he also published two excellent monographs, "Physiologie du Développement et Génétique" (Paris, 1935) and "Les Molécules Héréditaires" (Paris, 1939). Besides his researches, he founded in 1917 in Moscow the first Institute of Experimental Biology in Russia, of which for the rest of his life he was the loved and respected leader. He also founded and edited, until his death, the Biologicheskij Zhurnal, known to many British biologists. Among his students and colleagues were names so well known internationally as Zavadovsky, Serebrovsky, Efimov, Astaurov, Dubinin, Epstein, Filatov, Lopaschov and Manuilova.

I had the great pleasure of visiting Prof. Koltzov and his wife (also a research worker) in their laboratory and institute in 1935, and of appreciating the admirable atmosphere of collaborative work which reigned there among all its members. On November 27,1940 , Koltzov was interrupted in his work by a sudden heart attack. He was preparing a lecture which he would have delivered at the February, 1941, meeting of the Moscow Society of Naturalists. Its title was "Morphology and Chemistry". It was typical of him, this choice of a fundamental subject, 